\title{
Criminal Businessmen, Commodity Frontiers and the Colombian State
}

\author{
Marco Palacios \\ The College of Mexico
}

This article presents three micro-stories of Colombian businessmen of the criminal type who operated in commodity frontiers, known for the presence of intense public violence. In today's globalization, the Colombian economy made the transition from "coffee and industry" to "cocaine and services". Some authoritarian and modernizing policies of the Colombian State, mainly Uribe's Defense and Democratic Security Policy, DDSP, 2002-2010, have been central in the formation of a thick network of crime, business, public violence and politics as usual.

Our micro historic analyzes are based mainly on judicial cases that shed light on links at various levels: (a) the growing supranationality of drug trafficking and money laundering crimes; (b) the drug trafficking substrate in the appearance of the new commodity frontiers; (c) drug trafficking as a model of a business training school particularly in Colombia's internal frontiers and (d) the fundamental link between the local and the global in the perspective of organized crime and businesses.

Keywords: Commodity Frontiers, Crime, Business, The State, Microhistory

\section{CONCEPTS AND CASES}

This article addresses three judicial cases that could shed some light on the relationship between businessmen and crime in a country with a deficit of territoriality (Gouëset, 1999: 78-81) and legitimacy, at a time of transition from the era of "coffee and industry" to that of "cocaine and services". (Palacios, 2012: 99-136) In both eras, business activity appears as a de jure or de facto colonizing force, and as international economic expansion. (Palacios, 1980: 233-283) In a long-term historical perspective, (Braudel, 1968: 60-106) mining, quinine, tobacco, coffee, rubber, livestock, palm oil, or coca leaf adequately fall within the category "commodity frontiers" (Moore, 2000).

We will analyze businessmen who come directly or indirectly from drug trafficking, a form of organized crime that "acts in sectors ranging from a pure and peaceful market activity to a sheer, violent exercise of power". (Krauthausen, 1998: 38-41) A duality that forces them to compromise with political intermediaries, for example, with congressmen who write legislation, politics and business in a fluid matrix of the legal and the illegal.

Historical analyses indicate that the commodity frontiers in a global market are fertile ground for unraveling oppressive labor systems, deforestation or business activity. (Palacios, 1980: 161-179) ${ }^{2}$ In this paper, we will focus on the latter, starting from a small book edited in 1963 by anthropologist Fredrik Barth: "The Role of the Entrepreneur in Social Change in Northern Norway"; which, although unnoticed 
in the mainstream of business studies, caused stir in anthropologists dedicated to "ethnic groups and frontiers" and in historians focused on the field of microhistory. (P. A. Rosental, 1996: 141-161) Barth elaborated in a seminal article by Cyril S. Belshaw, also criticized the ethnocentric assumptions underlying many theories of economic development, such as those that only conceive the businessman in a market economy. Under such assumptions, in addition to running a business, seeking a profit, and taking risks, the central characteristic of the entrepreneur would be "innovation". According to Belshaw, in the primitive peasant societies of Melanesia and in his encounters with Europeans, the entrepreneur is not defined primarily by economic innovation, given the limited scope of possible decisions and the incipient technical base. In these situations, innovation happens at the level of cultural change because the entrepreneur is a leader who challenges traditions, seeking to expand the scale of his business, a phenomenon perceived directly, unlike, for example, the rate of profit expressed by numerical calculations unknown to most. The expansion of the scale of these enterprises increases the consumption of the community while requires greater human effort and the use of available resources. (Belshaw, 1955: 146-149) Although at the time this article was written there was little research on the interaction of "modern businesses" with "cultural elements external to the firm", (Belshaw, 146) here we propose an approximation taking recent cases from the Colombian internal frontier.

Also based on ethnographic research, Barth proposed that the businessman enters a chain of interpersonal relationships, decisions and transactions with the natural and social environment and the company is a sequence in time. Based on situations on the Norway-Lapland frontier, he elaborated several analytical concepts: niche, assets, restrictions, conversion channels. "Niche is the position he (the entrepreneur) occupies in relation to resources, competitors and clients." (Barth, 1963: 9) "Assets are the sum total of capital, skills and social claims which he may employ in the enterprise" (Barth, 1963: 9) "Skills" refers to the manipulation of both goods and people. The "restrictions" are the limits of the entrepreneur when he decides to negotiate with the agents affected by the exploitation of the niche. This negotiation takes place in the field of moral rules, since those potentially affected have options and are guided by the values prevailing in the respective community. To avoid community disapproval, the entrepreneur needs to find a "conversion channel", a way for the specific niche activity to move out of the community's own circulation "sphere" and into the market "sphere" where he hopes to maximize profits. For example, a community may consider that a salt mine is not on the market, cannot be bought or sold, but the salt, its product, does. This was the situation of salt mines and salt in the territories of the Muiscas at the time of the arrival of Europeans in 1537. Salt mines and salt belong to different spheres, like land and crops are also in different "spheres". In order to transform the "values" of the former into the "values" of the latter, the entrepreneur must make a technical, social and moral negotiation; he must find the most appropriate conversion channel. (Barth, 1963: 10-14)

Although Belshaw and Barth offer microanalysis of businessmen in pacified societies, it may be that the macro, state, and institutional levels are characterized by economic and political domination and control. In this article, however, it is accepted beforehand that violence continues to be an element of integration of the local socio-political order at Colombia's internal frontiers. (Palacios, 2012: 36-46; 5266)

The microanalysis of negotiations between local actors proposed by Belshaw and Barth encouraged us to assemble a fairly understandable picture of Colombian frontiers entrepreneurs and place it at a possible crossroads of political economy, business ecology and contemporary history. We worked on a couple hypotheses about the criminal entreprenurs who are the object of this article: (a) that for the already settled peasants the businessmen come from outside; they are, for example, the "Antioqueños en Córdoba y el Sinú" (Ocampo, 2007) and that more than innovators, they are expansive; and (b) that to establish channels of conversion they took advantage of the possibilities of Uribe's peace, understanding it as the combination of the Defense and Democratic Security Policy, PDSD, ${ }^{4}$ and parapolitic practices. (Palacios 2012: 62) 


\section{Frontiers, Public Violence, PDSD}

The concentration of rural property has accelerated considerably in recent decades. (IGAC/CEDE, 2012; Palacios, 2012: 196) As for land tenure, Colombia has one of the most unequal Gini coefficients in the world. (World Bank, 2004) From the landlord's power rooted in society and the State, derives the insecurity of rights of different peasant strata, magnified in recent decades by drug trafficking and associated violence, particularly on the fronts of colonization.

We are interested in three conditions that seem to worsen in colonization: (1) the open, covert or deceitful contempt for the law, backed by the routine use of violence. (Palacios, 2012: 94-98) (2) The latifundia and the plantation symbiosis with elaborate local clientele systems of medium and small owners. (3) The landowning power sponsors and benefits from the non-existence of a technical cadastre. This institution was established to guarantee the security and publicity of the legal title; to provide the State and citizens with updated information on the value of the properties and their agronomic potential. (Palacios, 2011: 15-41; 84-90; 200-205)

The political state of affairs, the short time in history (Braudel, 1968: 76-82) lets us glimpse how Uribe's peace took advantage of the global security agenda that Washington defined in the wake of the attacks of September 11, 2001. These dramatic, destructive, global episodes cancelled the viability Caguán Demilitarized Zone, a central element of President Pastrana's peace policy, and reoriented Plan Colombia, which was then in force, under a militarist line. (Palacios, 2012A: 175-206) In the midst of the 2001-2002 electoral campaign, Álvaro Uribe seized the opportunity by offering the country his "iron fist" policy as Antioquia's Governor (1995-1997) and focusing it against "international narcoterrorism". He highlighted the harshest passages of the anti-communist Cold War discourse gaining broad support from the political class, businessmen, popular sectors and the middle classes. Surprisingly, he won the presidency in 2002. (Palacios, 2012: 164-189) From the government he sponsored a constitutional reform to be re-elected in 2006 .

The PDSD was based on territorial control, investor confidence and social cohesion, "long term policy to achieve a society without poverty and with equality in income distribution". (Departamento Nacional de Planeación, 2007: 19-26) Shortly before the 2010 presidential elections, Uribe, who, according to a Constitutional Court ruling could not run for a third term, declared: "Look, there aren't any big prosperity roosters here yet, not even any small prosperity chicks yet. Yes, there are some eggs of prosperity. And we must take care of the hen that is laying those eggs. There are three little eggs of prosperity: that little egg of security, that little egg of investment trust and that little egg of social policy (...) while my fellow countrymen decide how they are going to vote in conscience, I am going to take care of this little chicken of trust".

Basically, territorial control was a point of military strategy with the imperative of recovering extensive territorial strips occupied by guerrillas and paramilitary gangs assimilated to foreign invaders. To that end, large-scale military operations were carried out, such as the Patriot Plan in southern Meta, Guaviare and Vaupés (2004-2006) through established procedures for combing and occupying territory. There was, however, an economic strategy of incentives and guarantees for large-scale modernizing investments such as improved breeds of livestock or the production of biofuels derived from sugar cane and palm oil. Since the recipe of "social cohesion" included additional incentives for big investors to forge "strategic alliances" with associations of medium and small producers, it should be analyzed step by step, along with the strengthening of the Fund for the Financing of the Agricultural Sector, Finagro, Fiduagraria S.A. ,the Livestock Funds, Fondos Ganaderos, and more focused programs such as those of Agro Ingreso Seguro, or the Caja Agraria (in liquidation, 2005-2006) that handled voluminous lines of subsidized credit and tax exemptions.

Based on resources from the US funded Plan Colombia, which were compensated in the National Budget, (Palacios, 2007) Uribe militarized the security policy by evaporating any notion of civil security. Taking into account the teachings of the counterinsurgency doctrines, he prioritized the propaganda war defining the FARC as the enemy of the nation: its core combined terrorism and drug trafficking. On the one hand, they had to be fought in the whole front line; on the other hand, it was not necessary to physically exterminate them because they produced votes. Their misdeeds against the civilian population 
fed a profitable political imagery, magnified with war propaganda techniques. (Palacios, 2012: 138-9; 142 ; 171-2; 186-7) Besides the heavy fiscal and financial cost, the PDSD concealed environmental costs and the concentration of land, discreetly continued under the government of Juan Manuel Santos (20082016) and who was Uribe's Defense Minister.

The three cases proposed in this article can be understood as independent frameworks, some located in Chocó-Urabá, others in Caquetá-Vichada, others in Putumayo. However, a national picture will be shown here. It is not rambling if we begin this story with Senator Miguel De la Espriella Burgos. A wellknown Colombian politician of recent times, he faced a trial in the Supreme Court of Justice (CSJ), resulted in a short sentence of 45 months in prison and the loss of some political rights. De la Espriella admitted in the trial that, together with other politicians, he had clandestine encounters with the United Peasant Self-Defense Forces of Córdoba and Urabá (ACCU), which had to be decisive in the elaboration of the "Ralito Pact" in 2001, the basis of the 2005-2006 Paramilitary Demobilization Agreement, a lever in the success of the Uribe's peace. (Palacios, 2012: 169-174)

Aligned at the time with pro-Uribe currents, De la Espriella has been one of the few who dared to reveal incidents that incriminate former President Uribe in parapolitical maneuvers. ${ }^{5}$ He was accompanied by bloodthirsty paramilitary leader Salvatore Mancuso, who is serving his sentence in the United States after being extradited in June 2015, and ex-congresswoman Eleonora Pineda, who also ended up with a short sentence in a parapolitics trial. Breed in political dynasties of Sucre and Córdoba, together with other colleagues, such as the liberal former senator for Córdoba Flora Sierra de Lara, De la Espriella was a protagonist in the wheeling and dealing in the Congress of the Republic that led in 2000-2001 to the laws that authorized the Livestock Funds to rediscount bank credits. ${ }^{6}$ It is important to stress and bear in mind that these laws were intended to strengthen the political and patrimonial power of local landowners. De la Espriella is a prominent figure in two of our micro histories: (1) as a beneficiary of huge embezzles by Miki Ramírez to Banco Cafetero, Bancafé, and Finagro using the intermediation of the Caquetá Livestock Fund (FGC). (2) For his duties as initial intermediary of the palm oil producers (Palmeros) with the notorious drug trafficking chief and paramilitary Carlos Castaño. The adventures of the bridgepolitician, as he calls himself, warn us about the limitations of localized studies of public violence in Colombia. De la Espriella is thus a character that represents the strategic link between the local and the national. Let's look at the cases.

\section{Case 1: Palmeros in Chocó-Urabá: The Modus Operandi of Land Grabbing}

The political sequence is eloquent: (1) The Palmero project always had the emblematic support of the Government of Antioquia and Medellín politicians since the time of Governor Uribe Vélez. The National Army caused the exodus of the black communities of Curvaradó and Jiguamiandó and the Palmeros entered to plunder the "ethnic territory" during the government of Andrés Pastrana, (1998-2002) (2) "Land purchases" continued during the Uribe government (2002-2010) and the project was consolidated thanks to different credit operations in the PDSD modalities. (3) Public denunciations of forced displacement and business plundering could be judicialized and prosecuted during the government of Juan Manuel Santos (2010-2018).

Since 2010, the judicial processes of the Palmeros have been a cause célèbre of plundering perpetrated against black and peasant communities in the name of, and on behalf of, agro-industrial modernization projects. (Ballvé, 2011; Franco and Restrepo 2011: 288-315) In May of that year, an attorney from the Human Rights and International Humanitarian Law Unit ordered the preventive detention of 24 citizens, possible co-perpetrators responsible for forced displacement in concurrence with aggravated criminal conspiracy and invasion of areas of special ecological importance in the Cararica, Salaquí and Truandó basins. Managers and assistants, some of whom were rather modest, operated a closed group of companies constituted mainly in Medellín and Barranquilla, as shown in Table 1.?

Most of the defendants in Table 1 received different types of prison and pecuniary sentences. Some paramilitaries ended up with early sentencing; others fled. On October 30, 2014, the Fifth Specialized Criminal Court of the Medellín Circuit sentenced 18 defendants to serve different sentences. 
TABLE 1

CITIZENS WHO WERE ORDERED PREVENTIVE DETENTION ON 18 May 2010

\begin{tabular}{|c|c|c|c|c|c|c|}
\hline $\begin{array}{l}\text { NAMES AND SURNAMES OF } \\
\text { INDICTED PALMEROS }\end{array}$ & $\begin{array}{l}\text { ROLE IN THE CRIMINAL } \\
\text { SCHEME OF PALMEROS }\end{array}$ & LEGAL ADDRESS & EDUCATION LEVEL & $\begin{array}{c}\text { CIVIL } \\
\text { STATUS }\end{array}$ & $\begin{array}{l}\text { PLACE OF } \\
\text { BIRTH }\end{array}$ & BIRTHDATE \\
\hline Gabriel J. Sierra Moreno & $\begin{array}{l}\text { Legal representative Palmas de } \\
\text { Curvaradó }\end{array}$ & Medellín & secondary school & married & Medellín & 7/1/1953 \\
\hline Claudio A. Fregni Ochoa & $\begin{array}{l}\text { Legal representative } \\
\text { Inversiones Fregni Ochoa }\end{array}$ & Medellín & business manager & married & Medellín & 10/22/1962 \\
\hline Héctor Duque Echeverry & Legal representative Palmado & Apartadó, Ant. & secondary school & single & La Ceja, Ant. & $9 / 10 / 1967$ \\
\hline Raúl A. Penagos González & Partner Selva Húmeda & Rionegro, Ant. & agricultural engineer & married & Medellín & 3/1/1959 \\
\hline Mario L. Villa Pacheco & Employee Urapalma & Belén de Bajirá & nd & married & Montería & 10/19/1959 \\
\hline Carlos D. Merlano Rodríguez & Lawyer Urapalma & Barranquilla & lawyer & married & Barranquilla & $6 / 3 / 1963$ \\
\hline Guillermo Ochoa Pino & $\begin{array}{l}\text { Owner manager Palmas de } \\
\text { Bajirá }\end{array}$ & Belén de Bajirá & secondary school & married & Cali & 1/31/1942 \\
\hline Luis A. Flórez Pérez, a. Ñeque & Crops Coordinator Urapalma & Belén de Bajirá & primary school & nd & Montería & 10/21/1972 \\
\hline Roberto M. Álvarez Vertel & $\begin{array}{l}\text { Legal representative } \\
\text { ACOPALMA }\end{array}$ & Montería & secondary school & married & Montería & $7 / 19 / 1964$ \\
\hline Jorge L. Santo Ortega, a. Gago & Watchman Urapalma & Belén de Bajirá & nd & cohabiting & Sincelejo & 6/11/1972 \\
\hline $\begin{array}{l}\text { Juan J. Palacios Palacios, a. El } \\
\text { Diablo }\end{array}$ & Land broker & Belén de Bajirá & primary school & separated & Rio Sucio, Chocó & $8 / 5 / 1963$ \\
\hline Manuel G. Denis Blandón & Land broker & Chigorodó & primary school & cohabiting & Murindó, Ant. & 9/3/1975 \\
\hline Mario A. Vélez Giraldo & Land broker and lawyer & Medellín & lawyer & cohabiting & Rionegro & nd \\
\hline Sor Enid Ospina Rendón & Lawyer Agropalma & Medellín & lawyer & single & Guadalupe, Ant. & nd \\
\hline $\begin{array}{l}\text { Hermén J. Muñoz González, a. } \\
\text { Diomedes }\end{array}$ & Land broker & $\begin{array}{l}\text { Cárcel Bella Vista } \\
\text { (murder) }\end{array}$ & $\begin{array}{l}\text { secondary school } \\
\text { incomplete }\end{array}$ & cohabiting & TierraAlta & $3 / 14 / 1966$ \\
\hline $\begin{array}{l}\text { Javier Morales Estrada, a. } \\
\text { Mocho }\end{array}$ & Farmer. Demobilized $A U C$ & nd & $\begin{array}{l}\text { primary school } \\
\text { incomplete }\end{array}$ & cohabiting & Cartago & 12/9/1962 \\
\hline Iván Patiño Patiño & $\begin{array}{l}\text { Partner and Legal } \\
\text { representative Palmas S.A. }\end{array}$ & Medellín & lawyer & married & Armenia & $3 / 10 / 1948$ \\
\hline Javier J. Daza Pretel & Manager Urapalma & Barranquilla & business manager & married & Barranquilla & 2/10/1962 \\
\hline Jiuvani Suescún López & Land broker & Mutatá & $\begin{array}{l}\text { secondary school } \\
\text { incmplete }\end{array}$ & cohabiting & Mutatá & $1 / 5 / 1978$ \\
\hline Danilo Pacheco de la Hoz & Land broker & Barranquilla & computer technician & cohabiting & Soledad, Atl. & $7 / 22 / 1968$ \\
\hline Antonio N. Zúñiga Caballero & $\begin{array}{l}\text { Legal reopresentative Palmura } \\
\text { and partner Urapalma }\end{array}$ & Santa Marta & civil engineer & married & Barranquilla & 8/5/1949 \\
\hline José M. Ruíz Cossío & Partner Selva Húmeda & El Retiro, Ant. & business manager & married & Medellín & 6/9/1971 \\
\hline Katia P. Sánchez Mejía & Manager Urapalma & Montería & tourist manger & cohabiting & Montería & 1/14/1956 \\
\hline Jesús I. Roldán Pérez & $\begin{array}{l}\text { Project Manager with Carlos } \\
\text { Castaño }\end{array}$ & $\begin{array}{l}\text { Penitenciaria La } \\
\text { Picota }\end{array}$ & primary school & married & Guadalupe, Ant. & $6 / 5 / 1968$ \\
\hline
\end{tabular}

Source: based in the Eighth Specialized Attorney's Office, Radicado Sumario 3856, May 18, 2010 and April 11, 2011.

According to the guilty veredict, "in the fulfillment of their commercial purposes, the legal proxies and/or partners of the aforementioned companies, in association with members of narco-paramilitary groups that had interference in the region, tried to legalize the occupation of the lands, which is why they resorted to the purchase and sale of land and dramatically increased its extension through the fraudulent use of the accession; they bought unsaleable land at ridiculous prices with forged documents, signed sales 
of real estate of deceased people, among other modalities; procedures with which they also backed bank credits and obtained state incentives". ${ }^{8}$ It is worth noting that the Civil Code distinguishes two distinct phenomena of accession: (1) what produces the good and (2) what joins it well. The Palmeros argued the second, meaning that the increase of thousands of hectares of their properties was due to the natural withdrawal of the waters of the rivers. The judicial processes proved that, on the contrary, the increase was fundamentally due to falsehood in the notary documents.

The narco-paramilitary association mentioned in the judicial sentence features several palmero leaders: Vicente Castaño, alias "El Profe", in Urapalma S.A., Palmura S.A. and Extractora Bajirá; Diego Fernando Murillo Bejarano, alias "Don Berna", in Palmas S.A.; Jesús Ignacio Roldán, alias "Monoloche", in Agropalma \& Cía. Ltda.; Raúl Emilio Hasbún Mendoza, alias "Pedro Bonito", in Palmadó Ltda. In the latter's statement to the Attorney's Office in 2012 he stated: "We have submitted lists of 270 banana producers, 400 cattle ranchers and 4,200 merchants who voluntarily contributed to the self-defense groups. Today they say that it was through the Convivir (Agricultural Self-defense Cooperatives) and that they had no knowledge; that's lies". 9"

Also convicted were land commissioners, members of the "illegal armed structure known as Casa Castaño", not listed in Table 1, as well as his stepsister, Sister Teresa Gomez, or Remberto Manuel Alvarez. ${ }^{10}$ In turn, Javier José Daza Pretelt, Hernán Iñigo de Jesús Gómez Hernández, Katia Patricia Sánchez Mejía and Gabriel Jaime Sierra Moreno made a final attempt, demanding the sentence before the Supreme Court of Justice, which dismissed the appeal. ${ }^{11}$

Antonio Nel Zúñiga Caballero, the most elegant defendant of the Palmeros, was able to move the trial from Quibdó to Medellín. ${ }^{12}$ However, in mid-2017, the Criminal Courtroom of Medellín's Superior Court sentenced him to 10 years in prison and a fine of 2,683 monthly minimum wages for the crimes of aggravated criminal conspiracy, forced displacement and invasion of areas of special ecological importance. ${ }^{13}$ Three companies, Urapalma, Palmas de Curvaradó and Palmadó, were sentenced to repair $\$ 10,600$ million pesos that Finagro had rediscounted, in part because of their "strategic alliances" with fictitious associations of small farmers. ${ }^{14}$ This section of the sentence could never be fulfilled because at the time it was executed the companies were bankrupt.

The judicial records describe in detail an "alliance between sectors of the legal economy, some members of the public force, facilities, and in some cases boost by public officials, actors of illegal economies - drug traffickers and smugglers - and Casa Castaño". ${ }^{15}$ For example, Katia Patricia Sánchez Mejía, manager of Urapalma, sentenced to ten years in prison, was the wife of Hernán Gómez Hernández, "the sybarite friend" and "intellectual tutor" of Carlos Castaño as he stated in his book "Mi Confesión”, (Aranguren Molina, 2001: 193-198).

In Colombia, the creation of conversion channels combines legal and coercive means; harmful private acts and exquisite public speeches; sealed paper and machine-guns. Moreover, all the judicial rulings cited from 2010 to 2018 highlight the role of the National Army and specially Operation Genesis. Executed from February 24 to 27, 1997 by the Army's XVII Brigade, it was under the command of General Rito Alejo del Río, “The Peacekeeper of Urabá". ${ }^{16} \mathrm{He}$ served a long prison sentence for murder in his anti-guerrilla outpost in Chocó, the former serviceman was recently released by resorting to the Special Peace Jurisdiction (JEP), which includes senior military commanders as beneficiaries, a point that was not contemplated in the initial Havana agreement between the government and the FARC. ${ }^{17}$

The 2014 judicial sentence established that, "in relation to the materiality of the behaviors, with respect to the criminal conspiracy, in the emergence of the criminal association there is a glimpse of the existence of the Peasant Self-Defense Forces of Córdoba and Urabá, called Casa Castaño, where the initiative to develop an agro-industrial project came from. In order to do this, the guerrillas had to be evicted from the basins of the rivers of the lower Atrato, which had prevailed for decades. This began with Operation Genesis (...) and later moved their activities to the basins of Curvaradó and Jiguamiandó, an action in which displacements took place. In the second place, it was necessary to locate the lands apt to develop these projects, for which the aforementioned basins were located as the most suitable for this type of crops, according to studies ordered by Vicente Castaño". ${ }^{18}$ He boasted to Semana Magazine: "In 
Urabá we have palm crops. I got the businessmen to invest in these projects by myself. The idea is to take the rich to invest in this type of projects in different areas of the country". ${ }^{19}$

General del Río coordinated the military occupation of the aforementioned basins with the Air Force and with Fredy Rendón Herrera, alias "El Alemán", head of the paramilitary front "Elmer Cárdenas". After heavy bombing, the infantry entered, and some 3,500 Afro-descendants, around 700 families, fled in terror. ${ }^{20}$ Their community territories, fertile land, were "bought" and occupied by the Casa Castaño and the Palmeros of Santa Marta and Medellín. ${ }^{21}$

Seeking the benefits of the Justice and Peace Law, Éver Veloza García, alias H.H., head of the Calima unit that operated in Valle del Cauca, Cauca and Urabá, confessed before attorneys and judges that he participated in the murder of some 3,000 people, mainly peasants, indigenous people and Afrodescendants. Although he was extradited to the United States in March 2009, he continued to testify before the Colombian courts. ${ }^{22}$ H.H. confessed that he was closely aware of the Castaño brothers' involvement in the construction of a 100,000-hectare "palm mega-project" in Chocó-Urabá. ${ }^{23}$ In a free version submitted to the Attorney's Office in September 2008, H.H. specified that "Vicente has said (...) that the road to Panama someday has to be a fact and (...) so that's why the objective of setting up that project there. (...) Once that road was built, it would be very easy to export at a very low cost."

H.H. also confessed having coordinated with several paramilitary leaders the electoral support for Popayán's politician Juan José Chaux. ${ }^{24}$ Now, Nel Zúñiga Caballero was a shareholder of Palmura, manager, partner and legal proxy of Urapalma. ${ }^{25}$ A member of a wealthy family of Santa Marta known for participating in urban and especially rural real estate businesses and for dubious transactions related to properties located within the Tayrona National Park, ${ }^{26}$ Zúñiga Caballero was politically related to Chaux, former governor of Cauca and ambassador to the Dominican Republic. Chaux had to resign from the Embassy when it was made public that he participated in a meeting with Pedro A. López Jiménez, alias Job, "right-hand man" of Don Berna's paramilitary group, in the office of Edmundo del Castillo, Legal Advisor to President Álvaro Uribe Vélez, Press Secretary César Mauricio Velázquez also reportedly attended. $^{27}$

Completing the family portrait, María Fernanda, daughter of Zúñiga, Chaux's niece, had been Liquidation Manager of the Caja Agraria in 2005 and 2006, precisely in the years when transactions were made in favor of the Palmeros. Like her uncle Juan José, she was forced to resign as Director of Sociedad Fiduciaria de Desarrollo Agropecuario S.A., a company dependent on the Ministry of Agriculture, after learning that she was a partner of Palmura S.A.

Based on credits from Banco Agrario (which replaced Caja Agraria) and Corporación Financiera del Valle, rediscounted in Finagro, several Palmeros legalized the properties through fictitious "peasant associations", set up by paramilitary groups or through rigged purchases. We have, for example, the case of Lino Antonio Díaz Almario, a peasant who bought 5,900 hectares in 2000 and immediately sold it to the Association of Small Palm Oil Producers of Urabá, an organization made by Urapalma. The truth is that Lino Antonio had drowned in the waters of the Jiguamiandó River in 1995, five years before these incredible sales of thousands of hectares were made. ${ }^{28}$

This story also involved USAID, an agency of the U.S. government that decided to conceive it as a simple alliance between "grown-ups and kids". The former invested in new land thanks to the latter, which benefited from it. USAID operated through $A R D$ Inc, a private company based in Burlington. In 2002, Urapalma applied to ARD for US\$700,000 in funding which, according to officials at the U.S. Embassy in Bogotá, was rejected in 2005 because the Colombian company did not send the required reports. It is striking that at that time USAID officials were unaware of the scandalous situation since 1997 , precisely as a result of Operation Genesis. ${ }^{29}$

\section{Contexts and Consequences of the Palm Oil Business in the Bajo Atrato}

The key period in the consolidation of the Palmero project was the Uribe's peace, when "securing the territory recovered from the guerrillas" implied generating a chain of intermediation networks, thus described in a judicial file: the "undue intervention (...) of individuals and companies with economic interests in the ethnic territory" in the processes of the community councils, with the purpose of 
"facilitating the negotiation of the territory", through induced migratory processes - repopulation-; the cooptation via the financing of the community spaces in which the representatives of the Councils are appointed, and the financing of campaigns to discredit the organizations that support the communities in demanding their rights. ${ }^{30}$

Although ethnic identity, intensely assumed after the constitutional and legal reforms of the last decade of the twentieth century, should be considered throughout the Pacific Strip (Wouters, 2001: 498519; Escobar: 2003: 157-167), the sentence of the Constitutional Court (CConst), T-025/2004, of Magistrates Luis E. Vargas Silva, Juan C. Henao Pérez and Nilson Pinilla Pinilla, who ordered the restitution of some one hundred thousand hectares to the black communities, has still not been complied with (Wouters, 2001: 498-519; Escobar: 2003, 157-167). One reason for the non-compliance is to be found in the development of customary practices of gamonalism that divide communities and feed "representation conflicts" between different "community councils", a few of them aligned with the Palmeros.

It is clear the contempt of the Palmeros for the 1991 Constitution, which defines Colombia as a pluralist nation of democratic and multi-ethnic development which recognizes the diversity of cultures and the political need to manage their harmony. (Vargas Silva, 2011; Pineda Camacho, 2001; Reales, 2011) According to the Constitutional Court, "The concept of territory is integral, it includes the land, the community, nature and the interdependent relationships of the diverse components, as well as the ancestral uses and customs linked to their habitat, expressed in the knowledge that the members of these communities inherit and in the knowledge of the rhythms and times to do the different activities". ${ }^{31}$

In the development of this issue, we must inquire about the real and potential role of local businessmen of African descent in relation to the big Palmero and Bananero projects. It is documented that broad sectors of the black communities consider the Palmeros and Bananeros to be voracious, violent and incapable of negotiating, thus generating broad moral and social disapproval. ${ }^{32}$ They simultaneously operated with paramilitaries with popular roots and were able to co-opt peasant associations.

The judicial testimonies coincide in that the Palmeros appeared suddenly and together with the military and paramilitaries; that they sowed fear, displaced populations, bought loyalties and were not affected by the disorder and suffering they caused in local life. They burst into the neighborhoods with the legitimate letterhead of the "modern businessman" who defends social claims, or the "social cohesion" proclaimed by the PDSD. ${ }^{33}$ In Urabá-Chocó, for example, the authorities in fact agreed with the "agrarian reform" that the Castaño family promoted with paramilitaries in collusion with the Armed Forces and with the business community, through the Cordoba Peace Foundation, Funpazcor. Large portions of the population did not agree. ${ }^{34}$

If the collective ownership of the black communities and the condition of the protected ecological area of their territories are advances towards legal equality, being considered "inalienable property", implies being out of the market and, consequently, the property cannot serve as collateral of Bank credit. The unintended effect of this situation is that among the black communities, international NGOs gained enormous margins of action and influence with their aid packages. (Vélez, M. A., 2009, 2011) If communities found ethnicity as a path to broadening citizenship, it has been more difficult for them to free themselves from the old agrarian individualism and fully accept the collective ownership of Law 70 of 1993, in implementation of Article 55 of the Constitution. The Palmeros and the politicians leveraged this individualistic mindset. They took advantage of local clientelist arrangements thanks to their political and family connections, imposed by the gamonales of which incessant disputes between community councils in the Pacific Strip are proof. (Franco y Restrepo, 2011: 411-442)

Since the legal laxity of the frontier is well known, predatory capitalist activity tends to be even more experimental than in the rest of the country. Apparently businessmen are exercising their right of conquest, the principle of "civilization" through the use of violence and ad hoc rules. In the gaps between their plantations they left small intermediaries, ordinary paramilitaries who gambled with life, wealth, biographical trajectory and family life.

In order to carry out the business, the Palmeros displaced the Afro-descendants. They exercised legal "acts of dominion" by hiring labor to build infrastructure and open "modern" plantations. They presented 
themselves as a symbol of legitimate values and manipulated the myths of the agrarian distribution and the self-made man. ${ }^{35}$ Finally, it was clear to them that corporate profit was not limited to the balance sheets. The strategy implied long-term individual and group benefits in the spheres of power, rank, prestige, or the willingness to grant or receive favors within agreed, implicit values, generally outside the law. In this sense, the Palmeros seemed willing to take risks that could affect the whole operation. In this case, they are willing to end up being accused of being criminals, although not in their social groups.

\section{Case 2: El Miki: from Cook to Paramilitary and Lord of Brangus in Caquetá and Rubber in Vichada}

How to explain that Miki Ramírez, one of many humble "cooks" who prepared cocaine in Pablo Escobar's organization, managed to conceive and successfully execute an elaborate and substantial embezzlement of Finagrario and Bancafé? Is El Miki an example of social mobility from the crime of drug trafficking, a school of business theory and practice? In times of La Catedral he was already dealing directly with Escobar. ${ }^{36}$ Frightened by the gruesome murders of his godparents ordered by Escobar, El Miki was among the first to report him to the Attorney General's Office, getting judicial benefits under the law. ${ }^{37}$ Later, he was part of a group known as the "Twelve of the Gallows". ${ }^{38}$ Released from prison, El Miki continued his criminal business career. Sponsored by chiefs Salvatore Mancuso and Vicente Castaño, he became a great landowner in Zambrano, Bolívar. A partner in paramilitary structures, El Miki was the protagonist of notorious misdeeds related to land plundering. He always linked the drug business with any other activity; therefore, the National Police identified him as one of the capos of the Caribbean Coast. ${ }^{39}$

In 2002, with a capital of $\$ 300$ million, he founded the company Agrolife, "a facade to hold the status of businessman in legal transactions". "Five years later he created another company with the same features: Colombian Rubber. ${ }^{41}$ Initially registered as "sole proprietorships", they were transformed into Limited Companies. ${ }^{42}$ Agrolife's partners were his bodyguards and minor name lenders. Unlike the cattle business partners, Colombian Rubber Board of Directors consisted of socially recognized individuals such as Congresswoman Flora Sierra de Lara. The two business firms served as a platform for the big scam.

\section{Clientelistic Rules, Bank Credit, Investor Confidence and Strategic Alliances}

Although Miki Ramírez seemed like an occupier in Caquetá, he skillfully played being a native of Florencia, its capital. He employed family and neighborhood relationships and appealed to personal loyalties by co-opting senior Bancafé officials in that city and in the main office in Bogotá. Thus, he got granted by the Manager of the Caquetá Livestock Fund (FGC), Carlos Alberto Bustos Rodríguez, a graduate of the National University, with a master's degree in Management from the Universidad de la Salle, ${ }^{43}$ his ex-employee and married to one of his sisters-in-law. ${ }^{44}$ These social ties explain the ease with which he managed to embezzle Finagro through clever agricultural portfolio credit operations with rediscount resources through FGC and Bancafé. Although the exact amount of the fraud is not known, it was estimated at about 50 billion pesos at present value in 2012 .

He developed three flagship projects: "caucheros" (Rubber producers), "grandes ganaderos" (Big cattle ranchers), "pequeños ganaderos" (Small cattle ranchers), reminiscent of small coffee growers. The last two were set in motion thanks to the FGC endorsement required to obtain the credits from Bancafé, which, in turn, managed the respective rediscounts with Finagro. He got professors from the University of the Amazon, Florencia, to scientifically and technically endorse his cattle projects: the implantation of

embryos of improved breeds, Brangus, a cross between Brahman and Angus, which would be imported from Uruguay.

The flow of money is a good start to understand the fraud scheme: approval of the respective project by FGC $\rightarrow$ Approval of the credit by Banco Cafetero $\rightarrow$ Deposit in FGC account $\rightarrow$ Deposit in Agrolife and Colombian Rubber accounts. Let's see.

The FGC approved the "pequeños ganaderos" scheme: those having 7 to 10 heads of cattle. It offered to link a thousand Caquetá ranchers to Brangus' embryo implant program and 'Must have at least 8,550 
head of cattle as collateral for the beneficiaries of the embryo implant credits". Thus the FGC formally presented the cattle ranchers to Bancafé and each one obtained a loan of $\$ 29$ million, for 8 years with a 3year grace period for the capital. The procedure was undertaken between November 2004 and October 2005. The FGC deposited in an Agrolife account responsible for handling the technical package and individual attention to each lender. Thus, loans of about $\$ 29$ billion were disbursed to 855 people. They weren't ranchers. A bodyguard of El Miki had enrolled them in Florencia, Bogota and Ibague.

The judicial record highlights assumed values of social inequality, something like habitus or, more precisely, "practical sense" in Bourdian sociology. (Bourdieu, 1987: 156) El Miki men recruited "illiterate (...) persons who were in dire economic conditions". They were offered "from $\$ 200,000$ to $\$ 400,000$ that they accepted by handing a photocopy of the ID and signing a bunch of blank documents with their fingerprints". They were housewives, construction workers, guards, housemaids. "They enjoyed a day's walk to Florence, lunch, including a resort, and on the way they watched a video explaining what the program was all about". In the walk they became citizens and "small cattle ranchers" because in Florencia a Bancafé official interviewed them, in groups of 20 to 50, to verify their status as potential clients. Returned to their places of origin and approved for credit, Agrolife received money from FGC and immediately wrote checks cashed over the counter until all funds were gone.

The project "Grandes Ganaderos" that received credits for about ten billion pesos, was actually a scheme of several fictitious companies, including Miguel De la Espriella, Flora Sierra de Lara and her son Esteban Lara. It was secretly linked to the "Cauchero" project. This came to light when these "companies" cancelled the loans early. How is it possible that businessmen engaged in livestock development projects, borrowers of soft loans with very low interest rates and high grace periods, decide to pay them off too early? The bizarre behavior is explained by the third project, "caucheros". Colombian Rubber endorsed by FGC for another credit line of Finagro, for about 30 billion pesos. The purpose: to develop 24 "associative projects" of rubber sowings in Vichada. This time the alleged rubber tappers all came from the municipality of Zambrano, Bolívar. As mentioned, sponsored by Salvatore Mancuso and Vicente Castaño El Miki had bought a hacienda there in 1994. El Miki transferred funds from the rubber credit to its "big cattle ranchers" and they cancelled the debts fraudulently and prematurely. Thus, in a blink of an eye and despite all the banking supervisions, his cronies and political sponsors pocketed public money and were left in the clear.

Although the FGC acted as the formal manager of all three projects, El Miki always maintained control. Sometime after Finagro disbursed the 30 billion pesos to the 24 rubber companies through Bancafé and FGC deposited in Colombian Rubber's account, officials realized that there were no rubber crops. Inquiring, as they should have done from the beginning, they discovered that the lands on which the rubber plantations would were someone else's. Finagro had no choice but to cancel the corresponding rediscount operations with the FGC, which would be intervened. That was not the end of the issue, as El Miki quietly cancelled the mortgages backing the "cauchero" project, shortly before the intervention of the Agricultural Warranty Fund, FAG, in May 2006.

At this point Finagro put the case in the hands of the Attorney General's Office. In February 2007, an Attorney of the National Unit for the extinction of the property right and anti-money laundering ordered the arrest of El Miki, his brother-in-law and four main accomplices, accusing them of the crimes of money laundering, criminal conspiracy, third party misappropriation, public document forgery, procedural fraud and name lending. At that time the accusation was limited to the embezzlement of the "Pequeños ganaderos". Although this operation was similar to the "Grandes ganaderos" scheme, it reveals the array of resources available to a businessman trained in the drug trafficking school.

It is worth highlighting that all the notary operations of incorporation and change of legal configuration of Colombian Rubber, as well as the criminal cancellation of the legal mortgages, known as "alzamiento de bienes" (lifting of assets), were performed before Notary 48 of Bogotá.

El Miki's career is built on a treacherous framework of misappropriation of agricultural portfolio funds under the protection of the milieu and expectations created by the PDSD and Colombia's military reconquest project, which included agro-industrial development packages such as rubber and highproductivity livestock. In the background of Caquetá or Vichada, severely ravaged by lawlessness and 
violence, archetypal departments of the virtual non-existence of a property cadastre, there are nomadic populations, recent settlements, forced displacements, people vulnerable to coordinated action by the military, paramilitaries, guerrillas, coca growers, cattle ranchers and state policy administrators who bring a strong class bias lest say racist bias.

The business exploitation of niches in commodity frontiers suggests underlying strategies, means of acquire, invest or exchange capital, promoted by the ideology of "investor confidence", with the financial, military and paramilitary backing of the State. The design and day-to-day development of such methods require a set of skills to build networks of local intermediaries. Take advantage of subsidized bank credit and transform the money into co-optation and organization of loyal legal-illegal groups and thus increase wealth and power. An additional skill underlies in these innovations: to present an image of a responsible leader. El Miki showed himself as a benefactor businessman on the way to the progress of Caquetá and Vichada. The rural environment offered him the tradition and the PDSD the means to be worthy lord of the Brangus and rubber planter at the technological frontier. Although he could have been, he traded for another normality of the Colombian moment: paramilitary fraudster.

\section{Case 3: The Short Parable of David Murcia Guzmán, DMG}

On December 16, 2009, the Fourth Criminal Judge of the Bogotá Circuit found David Eduardo Helmut Murcia Guzmán, DMG, liable for the crimes of aggravated money laundering and massive and routine fund-raising. He was sentenced to 30 years and seven months in prison; to pay a fine of 50,000 minimum monthly wages; to repair 1993 persons listed as victims. He also decreed the extinction of ownership of 57 properties in his name, 50 of which were parcels in an urban development of Santa Marta.

Shortly before, on October 14, the Supreme Court of Justice had favorably granted a request from the Government of the United States of America to extradite him, indicted by the Southern District Court of New York for money laundering. The accusation referred to a typical crime scheme: through a middleman, DMG opened a bank account in the United States and deposited two million dollars by wire transfer from Mexico. The origin of the amount could be detected in an operation of exchange of Colombian pesos to dollars performed in the black market. Once the account was seized, no one came to claim because DMG ordered its agent to ignore the matter in order to hide the real origin of the funds. On July 8, 2011, a Federal District Judge sentenced him to 108 months in a U.S. jail.

In Colombia and the United States, the defendant pleaded guilty to laundering drug money and apologized. Upon completion of his sentence in the United States, he will be sent to a Colombian prison.

For a man who was not 30 years old, such a gloomy ending must have been unthinkable; such a sudden fall when he still felt the vertigo of the ascent. DMG's parable contains the elements of a "stratum 1" Colombian, the lowest in the statistical classification of "social strata" of Bogotá, with eight years of schooling, born in 1980 in Ubaté, who found and knew how to exploit niches in the jungle. Established in La Hormiga, the center of drug trafficking in Putumayo, DMG set up a brand new holding company. Transformed into the head of the "DMG family", he embodied the business leader. (Ramírez, 2014: 35) It acted in an environment in which the inhabitants, recent settlers, participated in coca activities "as a way of answering both their marginalization and the hegemonic socioeconomic and political order that has criminalized them", which punishes them through rigid policies of "fumigation and militarization", especially of the poorest. (Ramírez, 2014: 34)

Unlike the Palmeros or El Miki, who sought to navigate under the radars of the media, DMG enjoyed his public figure displaying himself in "bullet-proof cars, surrounded by bodyguards and beautiful women". An early report in Cambio Magazine, following the inauguration of a television channel, Body Chanel, pointed this out. The event had happened four months earlier at the Irotama Hotel in Santa Marta. It was attended by celebrities, media and businessmen from all over the country and from Mexico, the United States and Venezuela. It was a feast of three days and nights. 300 guests, all expenses paid, "despite the flamboyance and the spend (...) did not outshine the presence of Alicia Machado, the Venezuelan who was Miss Universe and was the star of the event".

Journal of Applied Business and Economics Vol. 21(6) 2019 
Officials at the Superintendence of Finance (the body responsible for the control and surveillance of financial institutions) began to suspect the DMG holding company. It was enough for them to see the list of the locations, the ones located in recognized coca growing and drug trafficking zones stood out: Bogotá, Santa Marta, Suesca, Duitama, Montería, Mocoa, Buenaventura, Villavicencio, Granada, Tunja, Pasto, Popayán, Monte Líbano, Puerto Asís, La Hormiga, Orito, Llorente, Villagarzón, Armenia, Sibundoy. In January 2007, the Superintendency warned the public. Two months earlier, a House representative for Putumayo had asked the Attorney General to investigate DMG and other companies that openly operated prepaid cards in the south of the country. For the time being, the Attorney General's office disengaged.

Although DMG understood the rules of public violence in Colombian coca areas, he chose the path of peaceful negotiation. He had begun training in Pitalito, gateway to the Colombian Amazon. There he established the DMG Solidarity Network that operated car raffles or managed health care subsidies for low-income people. He also ran a show on a local radio station. He became an enemy of the mayor, and the lady with whom he was staying advised him to take his business to La Hormiga. She put him in contact with a friend who, as he later said, "introduced me to the mayor, the pastor, the local channel and gave me all the tools" And so, he showed up in the Perpetuo Socorro parish in the downtown of La Hormiga and opened a program in the community radio station that, via paid advertising, gave him daily sustenance. (Ramírez 2014: 37-41)

To join the Amazonian milieu, it was necessary to understand the local meaning and hidden codes of the coca-growing economy. High liquidity on the one hand and, on the other, very restricted banking services in relation to other places in the country, since, under the conditions of national and international legislation on money laundering, coca areas are very high risk for banks. The absence of commercial banks explains the predominance of usury systems. The Putumayo villages are swarming with "drop by drop" loans that are paid daily at a monthly interest of $10 \%$. The same is true for the system of catalogue sales of products which, although in demand in the most rural and remote villages, were not distributed in the municipal centres.

Having deciphered these financial and commercial practices, DMG set up a network of catalogue sellers. As the business prospered, he trained more salespeople who received good commissions. In this way, he created a work clientele, a base of faithful people. Simultaneously expanded the line of business. From selling natural products and fragrances he went on to clothing, motorcycles, household appliances. In 2003 and 2004 it had stores in the towns of La Hormiga, Orito, Puerto Asís and Mocoa. Attending a business training course, he heard that the value of the Coca-Cola brand reached tens of billions of dollars. It was like the sign: from that moment on, he dedicated himself to "positioning" the DMG brand inside and outside the country. (Ramírez, 2014: 38-9) Let's take a closer look at his methods.

\section{DMG: Its Method Against the Truth of the Judicial Process}

Before the Fourth Criminal Court of the Bogotá Circuit, the Attorney General's Office presented 91 pieces of evidence (audios, videos, authorized telephone interceptions) of events attributed to DMG that constituted crimes of aggravated money laundering and massive and routine fund-raising of money. Experts from the Superintendence of Finance, the Superintendence of Corporations, (the body in charge of the control and surveillance of corporations and commercial companies) the Directorate of National Taxes and Customs (DIAN) and the Financial Research and Analysis Unit (UIAF) of the Ministry of Finance testified that they had set the spotlights on the activities of the DMG Holding, that is, "an immeasurable tangle of financial circuits, where on account of large businesses of simple appearance they wanted to hide unlawfulness, as to the origins of their capital".

The accusation was based on this premise: "from being a modest street merchant of natural products, in forgotten and distant villages, immersed in misery, as observed in the photographs that their witnesses brought to trial, suddenly, so, overnight, without for the sake of development having been illuminated by some economic genius, DMG became a prosperous businessman, of unsuspected economic power, with transnational reach, self-proclaimed president of the business group (...)". 
His lawyers argued that the holding was protected by the principle of business freedom in Article 333 of the Constitution: economic activity and private initiative are free as long as the common good is respected so that no prior permits or special operating requirements may be required for its operation. Under this umbrella DMG had mass-marketed prepaid cards. Since 2006, each card had been capped at $\$ 9$ million pesos; the same person could buy up to five cards that were used to make advance payments in the purchase of goods, hire services and even participate in schemes to promote the businesses of Grupo DMG S.A. In addition, cardholders received bonuses for "fidelizing" new customers and making personalized advertising for direct sales. Abelardo De la Espriella, his lawyer, described DMG as a company that "is not like banks... DMG does not take away, but on the contrary gives". He categorically stated that "DMG has no money laundering and is a transparent company".

In Colombia, the chain of drug trafficking operations, from production to laundering, has been the subject of legislation and intergovernmental information and monitoring systems such as The Financial Action Task Force (FATF). According to international and Colombian doctrine and jurisprudence, it is not necessary to prove that the accused knows the specific origin of the funds; "intentional ignorance" is enough so that the authorities do not have to prove their illicit origin. It is established the autonomy of the crime of laundering or illegal enrichment from its source crime.

The FATF presumes that prepaid card issuance and corporate schemes created to evade financial oversight are modus operandi of money laundering. According to the accusers, DMG laundered money by recruiting "local people, who had access to the services of prepaid cards, so that they would appear as partners of the companies constituted by themselves". They presented to the judges the stages or moments of a criminal sequence that began in April 2005. The following December, and "without the company having developed its corporate purpose and generated operating or non-operating income, it received from its partners as a loan of \$ 2,696 million pesos, of which DMG lent \$1,135 million pesos". The supposed "operational income" was made through an account of the Agrarian Bank making cash deposits, fractioned and in round numbers, from Puerto Asís, Mocoa, Orito, La Hormiga, Monte Líbano and Montería, places where the partners had no economic activity. Not to mention that they lacked the economic capacity to set up the company and then input such capital.

In October 2007, the Superintendence of Finance determined that this fund raising was illegal and ordered the suspension of the sale of DMG prepaid cards and the return of all monies raised. This is because the commercialization of DMG prepaid cards did not have as its main purpose the sale of goods and services but a primarily financial purpose; for example, while in the first quarter of 2007 sales of prepaid cards from 2006 to March 2007 amounted to \$21,744 million, the products delivery in the same period was $\$ 3,199$ million, only $14.7 \%$ of what was raised.

The attorneys concluded that "David Eduardo Helmut Murcia Guzmán, (...) supplanted the banks in the exercise of purely financial activities, for which he was not authorized by the State. It attracted a heap of deposits offering unusual yields, capturing from the public millionaire mounts through prepaid cards that could surpass $\$ 4$, billion pesos, under the protection of schemes such as the sale of goods and services, word of mouth advertising, sale of shares, etc. It was adopted as a reserve mechanism to cover withdrawals, exorbitant and unsuspected investments, in Colombia and abroad, spending people's money as their own".

\section{DMG: Politics and the Ephemeral Court of Public Opinion}

The history of DMG can also be a history of politics and (de)formation of public opinion. Promoting himself with his "brand" generated an ambiguous image in the media. He did not fit well in the bipolar scheme of good and bad in times of drug trafficking and "easy money", of economic freedom and social mobility. Over time, however, gaps opened up in social perceptions. While in many parts of the country, starting with Putumayo, DMG acted as a paternal figure, in the high circles of power, particularly in banking, led by Luis Carlos Sarmiento Angulo, he became an uncomfortable figure. Sarmiento, a selfmade banker had become a vital creditor to one of the most important and well-established newspaper companies of the 20th century. 
While DMG was ranked 655th out of the country's top 1,000 in mid-2008, the horizon clouded at the end of the year when the pyramids began to fall. Criticism poured down on the national government for its passivity in the face of an issue that affected thousands of small savers. Radio listeners and television viewers realized substantial losses of small and medium savers, modest people in Cali, Popayán, Pasto and Pereira, victims of Fast Easy, Money, Cash, DRFE, the biggest Ponzi scheme of this time. The press, previously lenient and even flattering about the pyramids, began to relate them to the fall of major U.S. banks by equating the relatively modest Colombian schemes with "The fall of Lehman (...) the onset of the economic crisis". Taking a 180-degree turn, the country's mainstream media stopped presenting the pyramids as "the magic formula" for making money. They found "precedents" in Albania and Russia. They lined up artillery against the government while forgetting that they had recently praised the DMG business. Moreover, they had assimilated it to the pyramids when, actually, it was a well-oiled drug money laundering machine. After all, DMG had risen to the corporate firmament in this milieu of investor confidence and moral and legal leniency. Even the president's sons recognized "a small participation" in Body Channel programs, something they later denied.

At the end of 2008 DMG clashed with President Uribe, whom he had generously financed in election campaigns: "he doesn't know what his children are doing. He's a bad president and a bad father". Fearlessness marked the point of no return. The entities that monitored their accounting, commercial correspondence, banking movements, showed their cards: DMG ran a "pyramid" business; they suspended their activities and raided more than sixty branches throughout the country. The confrontation with the president and the leader of the country's bankers was open.

Fallen in disgrace, even his lawyer abandoned him. It's not a trivial matter. DMG, according to a judicial document, "had so much control over its business that it was meticulous about its legal significance. The dialogue he held with Margarita Pabón Castro on August 20, 2008, starting at 9:42 a.m., in call 6, contained in evidence one hundred and twenty-five (125-F), is paradigmatic, in order to maintain with complete certainty that he was aware of the illegality of his conduct. It clearly appears there that at least two legal strategies were thoughtfully put forward to overcome the legal pitfalls of money rising. One, influencing politically in the Congress of the Republic, to reform the law, through the lawyer Abelardo De la Espriella, to whom they paid $\$ 760$ million; and another, to overthrow the norm as unconstitutional, that which people claim, that they can do with their money whatever they want, through prestigious lawyers, that charged him astronomical sums, in dollars. In both cases, because there is a quarrel with the Banking Association (Asobancaria); the purpose was to overthrow the rules of the financial system".

The public discovery and exhibition of the lifestyle maintained by the "Head of the DMG family" in Panama tarnished his social prestige, even among the most loyal. He crossed the line with yachts, airplanes, Lamborghinis, Ferraris, Maserattis, Mercedes Benz ... About 15 assets valuated at about five billion pesos, not including a sumptuous apartment, a jet plane, a twin-engine plane and three other luxury yachts.

The file transcribes a revealing telephone dialogue between DMG and Daniel Angel Rueda, DAR, his accomplice and crony from upper-class Bogotá, held on March 7, 2008:

"DMG - Hello faggot, you gotta see, I got all my cars convertible up there, jerk.

DAR - Yeah!

DMG - I got all the rides, all the cars are convertible, even the white Maseratti is there in the garden.

DAR - Have you delivered the white one yet?

DMG - The white, the yellow, the orange, which one do you want? You're all convertible. (laughs)

DAR - Really faggot?

DMG - They're all convertible.

DAR - Now we have the collection complete?

DMG - Yes, all of them are in the garden

DAR - Finally Bro. 
DMG - And all of them have their original top, the yacht is ready, you'll see how Andrea and I got the house, with all the ironwork, office, computer, TV in all the rooms, curtains, my God!

DAR - Right, ok pal very good.

DMG - Yes, we got everything.

DAR - Ok then ...".

The fact that DMG had its first encounters with the goddess of fortune in La Hormiga, Putumayo, a small Amazonian colonizing village on the Colombian side of the border with Ecuador, dissipates any idea that the frontiers are disjointed from the country or the world. Right there begins (or ends) a worldwide web. The hidden face of the territoriality deficit reveals an international capitalist order that integrates hundreds of thousands of rural localities in a dominant grid. So important, until its fall, DMG was considered in Putumayo, perhaps in the rest of the country, as a leader, a model of business person. It really seems irrelevant that he played within the parameters of Uribe's peace given that it the moment of truth he did not have the political resources to clean up after the laundering.

\section{CONCLUSIONS}

All three cases reveal that at commodity frontiers the market economy is intertwined with structures and situations of power. In other words, access to land, credit, technology, or the ability to anticipate the construction of infrastructure do not depend on supply and demand. The size of the companies is important, and, under conditions of a relatively static production function, the business strategy seeks expansion, either directly or through "strategic associations" of producers of different types and sizes. This is the case with palm oil or high yield cattle ranching and rubber. This seems to demonstrate all three cases:

(1) The case of the Palmeros of Urabá-Chocó, that tied businessmen from the upper class and the political class of Santa Marta and Medellín with paramilitary narco-owners of AntioquiaCórdoba. In collusion with politicians and officials of the Colombian Institute of Rural Development, INCODER, and the Notary and Registry system, they acquired titles of collective land of afrodescendant communities that had been displaced by the Army. They spiced up the business thanks to promotion credits within the institutional framework of the PDSD.

(2) In the case of Luis Enrique Ramírez Murillo, alias El Miki, we have a daring climber who began in the "kitchens" of Pablo Escobar's organization. In these facilities, coca paste was transformed into alkaloid; they are located in remote areas, preferably next to clandestine airstrips. When the Escobar emporium was dismantled, Ramírez managed to jump to paramilitary leader, landowner, businessman. Simultaneously managing client networks and the PDSD's discourse, carrying out one of the biggest scams to the Colombian financial system, simulating being a "high productivity" cattle rancher and rubber tapper in Caquetá and Vichada.

(3) Finally, we offered the parable of David Murcia Guzmán, DMG, a young man of humble origins, a remarkable financial entrepreneur who amassed profits and power from the modest trade of being a street merchant in Pitalito. He entered Putumayo and there his business action and discourse gained public acceptance. He succeeded in filling the void of commercial banks in coca-growing areas, while erasing the social stigma of local populations. In a vertiginous upward trajectory, he ended up associated with narco-traffickers and politicians of national stature.

The judicial system stepped in in all three cases. The businessmen were judged and condemned; their shiny companies collapsed. The consequences were paid by some two hundred thousand individuals, families, small businesses, seduced by the DMG scheme, or "mixed economy" entities such as Banco Cafetero and Finagro, destined to development credit, backbones of the PDSD. In the end, the taxpayers paid for the fiasco. 
It is possible that these judicial cases will shed light for future investigations on the role of commodity frontiers and its entrepreneurs in Colombian history, from the Spanish Conquest, with its encomenderos, corregidores de indios, frailes, visitadores, escribanos, to the era of global capitalism and of a Colombian political situation crossed by public violence, state fragility and political practices of plundering; by the vulnerability of local populations; the rise of mafia politicians, professional patriots, corrupt officials, fledgling ideologues and scavengers from the popular strata.

\section{ACKNOWLEDGEMENT}

I am grateful for the generous comments made by my colleagues from the Business History Group of the University of the Andes, Carlos Dávila, Xavier Durán and Carlos Eduardo Hernández, and by Alicia Puyana, Mónica Serrano, Ann Farnsworth-Alvear and Amy C. Offner.

\section{ENDNOTES}

1. Dr. Guillermo Puyana Ramos, attorney for the aggrieved parties, provided me with the court records of the cases presented here. Additional court records and Colombian courts veredicts are also available online as indicated below.

2. I have been guided in the understanding of the historical and social context in these areas by the contributions of renowned scholars who work on frontiers: Ramírez, (2014); Roldán, (2003); Steiner, (2000); Ortiz, (1998); Arocha, (1998); Wade, (1993); Taussig, (1987); Domínguez, (1986).

3. The official text of the Defense and Democratic Security Policy (PDSD) is available on: https://www.oas.org/csh/spanish/documentos/Colombia.pdf

4. Statement by the president Álvaro Uribe Vélez, Santa Rosa de Osos, May 26, 2010, available on http://historico.presidencia.gov.co/sp/2010/mayo/26/13262010_i.html retrieved April 14, 2012. Half a year after this speech, "Los Rastrojos", begotten by the United Self-Defense Forces of Colombia (AUC), committed one of the most frightening massacres of peasants in recent history. (Semana, 2012; El Espectador, 2012, El Tiempo, 2012, 2012a)

5. De la Espriella: "I was a bridge between Uribe and the AUC for Ralito's negotiation.". VERDADABIERTA.COM, September 25, 2012, retrieved June 12, 2013 from:http://www.verdadabierta.com/component/content/article/-/4232-de-la-espriella-y-pineda-eran-elenlace-de-los-paras-con-uribe-mancuso/; "We were spokespersons for Mancuso", El Espectador, October, 2012, p. 10.

6. "Background to Law 676 of 2001", in Congressional Gazette (GC), № 235, 21/05/2001; Bill No. 070 of 2000, Chamber, regulating the financial intermediation of Livestock Funds, in GC, $\mathrm{N}^{\circ} 373,18 / 09 / 2000$; [Author: honorable congressman Miguel Alfonso De la Espriella Burgos]. Presentation for first debate to bill 070 of 2000, Chamber, by means of which Law 510 of 1999 and Law 363 of 1997 are regulated and some dispositions are dictated on the rediscount of credit operations with the Fund for the Financing of the Agricultural Sector, Finagro, and on the granting of the livestock capitalization incentive., in GC, $\mathrm{N}^{\circ} 427$, 24/10/2000; Text of Bill No. 070 of 2000, Chamber, Approved in first debate in the Third Permanent Constitutional Committee of the Honorable House of Representatives, by means of which Law 510 of 1999 Definitive text to Bill No. 070 of 2000, Chamber, Approved in second debate in the plenary session of the Honorable House of Representatives on Friday, December 15, 2000, by means of which Law 510 of 1999 and Law 363 of 1997 are amended and some provisions are dictated on the rediscount of credit operations with Finagro, and on the granting of the livestock capitalization incentive in GC, $N^{\circ}$ 08, 26/01/2001 and Law 363 of 1997 are amended and some provisions are dictated on the rediscounted credit operations with Finagro, and on the granting of the Livestock Capitalization Incentive, in $\mathrm{GC} \mathrm{N}^{\circ} 464,22 / 11 / 2000$;

7. Attorney's Office. Radicado Sumario 3856, f. 2, 19-37

8. Fifth Specialized Criminal Court of the Medellín Circuit, Sentence 054 of October 30, 2014. f. 5.

9. "What Vicente Castaño was going to tell Justice", Verdad Abierta, May 15, 2012 in: https://verdadabierta.com/la-ultima-version-de-vicente-castano-antes-de-desaparecer/ See also, InterChurch Commission for Justice and Peace, "Banacol, a company involved in paramilitarism and land grabbing in Curvaradó and Jiguamiandó", May 2012 in: 
http://www.askonline.ch/fileadmin/user_upload/documents/Thema_Wirtschaft_und_Menschenrechte/Lebe nsmittel_Landwirtschaft/Chiquita/Banacol-Estudio-de-Caso-ES-final.pdf

10. Sentence 054 , cit., f. 5-6.

11. Supreme Court of Justice. Cassation No. 50832 of 30 August 2017, retrieved from: http://181.57.206.12/sentencias/Penal/2017/Dr.Jos\%C3\%A9\%20Luis\%20Barcel\%C3\%B3\%20Camacho/A P5662-2017(50832).doc

12. See Supreme Court ruling of August 24, 2011. Criminal Cassation Courtroom, Case No. 36991.

13. Ruling of the Superior Court of Medellín, Criminal Courtroom of May 30, 2017, Filed, 05001-31-07-0022014-00388, rescued October 16, 2017 from

https://www.salapenaltribunalmedellin.com/images/pdf/providenciaspenal/009/050013107002201400388\% E2\%80\%93ley-600.pdf

14. Fifth Specialized Criminal Court of the Medellín Circuit, Sentence 054 of 30 October 2014, ff. 335-37.

15. Superior Court of Bogotá, Justice and Peace Courtroom. Rad. 11001-256-2006-81009, ff. 157-158.

16. "Rito Alejo led alliance with AUC during criminal attack in Chocó", in http://www.eltiempo.com/archivo/documento/CMS-12162241 El Tiempo, August 25, 2012, retrieved September 28, 2014.

17. For political context see: "Jurisdiction of peace, yes, but with limits", Verdad Abierta, March 14, 2017, in https://verdadabierta.com/jurisdiccion-especial-de-paz-si-pero-con-limitaciones/ retrieved July 17, 2017. For the news of Del Río General, see: https:/www.elespectador.com/noticias/judicial/libre-el-general-ritoalejo-del-rio-articulo-715392; retrieved March 28, 2018.

18. Fifth Specialized Criminal Court of the Medellín Circuit, Sentence 054 of October 30, 2014. f. 18.

19. "Vicente Castaño speaks out", Semana.com, retrieved March 4, 2012 from: http://www.semana.com/portada/habla-vicente-castano/87628-3.aspx.

20. Attorney's Office, Radicado Sumario 3856, ff. 2, 180; OEA, Inter-American Commission on Human Rights, Report 64/11, Case 12.573, retrieved January14, 2013 from:

https://www.oas.org/en/iachr/decisions/court/12.573FondoEng.pdf; "Twelve paramilitaries led the army in Operation Genesis: ‘El Alemán”” retrieved January 5, 2014 from: http://www.verdadabierta.com/justicia-ypaz/versiones/2129

21. Fifth Specialized Criminal Court of the Medellín Circuit, Sentence 054 of October 30, 2014. ff. 14-18, 234, 26-30

22. See, "H.H.'s sentence, a priority in Justice and Peace", Verdad Abierta May 2, 2003, in: https://verdadabierta.com/inicio-priorizacion-de-crimenes-del-bloque-calima/ retrieved January 12, 2017.

23. Fifth Specialized Criminal Court of the Medellín Circuit, Sentence 054 of October 30, 2014. f. 15.

24. See note 22

25. Fifth Criminal Court, f. 17.

26. See also, "The Tayrona is of very few Colombians", El Espectador, October 10, 2009, retrieved August 28, 2012 from: http://www.elespectador.com/print/165962,

27. "Who was Alias Job?", in https://www.elespectador.com/noticias/judicial/quien-era-alias-job-articulo569283, retrieved April 12, 2016; "Government financed 100\% of the palm", in Inter-Church Commission for Justice and Peace, March 10, 2009, retrieved July 4, 2010 from:

http://justiciaypazcolombia.com/GOBIERNO-FINANCIO-CERCA-DEL-100-DE

See, "H.H.'s sentence, a priority in Justice and Peace", Verdad Abierta May 2, 2003, in: https://verdadabierta.com/inicio-priorizacion-de-crimenes-del-bloque-calima/ retrieved January 12, 2017.

28. Radicado Sumario 3856, ff.128-9

29. "The Dark Side of Plan Colombia", The Nation, June 15 2009, retrieved May 11, 2014 from: http://www.thenation.com/article/dark-side-plan-colombia

30. "The emblematic case of the collective territories of the black communities of Jiguamiandó and Curvaradó in the Urabá region" in,

http://www.indepaz.org.co/wp-content/uploads/2012/03/607_El-caso-emblem\%C3\%A1tico-de-losterritorios-colectivos-de-las-comunidades-negras-de-Jiguamiand\%C3\%B3-y-Curvarad\%C3\%B3-en-lar.pdf retrieved May 14, 2012

31. CConst, Auto A-045/2012, Luis E. Vargas Silva

32. Perhaps the fullest narrative on the subject is available from REPORT No. 64/11. CASE 12.573 MERITS MARINO LOPEZ ET AL. (OPERATION GENESIS) COLOMBIA. March 31, 2011 in https://www.oas.org/en/iachr/decisions/court/12.573FondoEng.pdf retrieved May 14, 2014. 
33. Álvaro Uribe Vélez, Report to the National Congress, 2007, pp. 114, 122-1233, 125, 127 y 195. Retrieved June 14, 2012, rescued May 22, 2014 from:http://wsp.presidencia.gov.co/dapre/Documents/InformeCongreso/Informe_congreso_2007-AUV.pdf.; Álvaro Uribe Vélez, Report to the National Congress,2010, pp. 233-244; retrieved May 22, 2014 from: They received public subsidies and tax exemptions; http://wsp.presidencia.gov.co/dapre/Documents/Informe-Congreso/Informe_congreso_2010-AUV.pdf

34. "The fraud of the Castaño to plunder". VERDADABIERTA.COM, September 12, 2012, retrieved March 1, 2014 from: http://www.verdadabierta.com/component/content/article/48-despojo-de-tierras/4239-lasmentiras-de-los-castano-para-despojar; "The agrarian reform of the Castaño was a fake", in eltiempo.com, March 18, 2014, retrieved March 20, 2014 from: http://www.eltiempo.com/archivo/documento/CMS13676196; Ministry of Agriculture, Land Restitution Unit, "Story behind the agrarian reform of the Castaño brothers" April 2, 2014, retrieved March 28, 2018 from: https://www.arcoiris.com.co/2014/04/unahistoria-tras-la-reforma-agraria-de-los-hermanos-castano/

35. The accused Palmeros left the land and their companies collapsed. Many of the former workers who were accomplices in the plundering and didn't want to leave the area, claimed rights and confronted Afrodescendant communities. See, "Colombia; the ranchers accused by the victims in Curvaradó and Jugimiandó", La Silla Vacía, May 14, 2012, retrieved 19 October, 2017 from: https://www.plazapublica.com.gt/content/colombia-los-ganaderos-acusados-por-las-victimas-en-curvaradoy-jiguamiando

36. The Cathedral is the name of a Pablo Escobar estate located near Medellín that would be the prison the capo agreed with the government of César Gaviria Trujillo when he surrendered in June 1991, in exchange for not being extradited. Escobar continued to run the drug business from there until his spectacular escape in July 1992.

37. Established by Decree 1833 of 1992; see Diario Oficial No. 40.668 of November 14, 1992, and Bogotá Circuit Criminal Court, Ordinary Judgment No. 7, ff. 8 and ss.

38. Journalistic syntheses can be found in "The Twelve of the Gallows"., Semana, February 20, 1995, retrieved July 30, 2012 from: http://www.semana.com/nacion/doce-del-patibulo/43301-3.aspx, y "The Twelve of the Gallows", Semana, August 7, 2005, retrieved June 26, 2012 from: http://www.semana.com/nacion/12-delpatibulo/89082-3.aspx.

39. As part of the paramilitary occupation process of Montes de María, (Mancuso y Vicente Castaño) El Miki bought the Hacienda "El Hacha", in Zambrano, Bolívar. Seer, How was forged the tragedy of Montes de María? Verdad Abierta, September 2, 2010, p. 4, retrieved August 15, 2012 from: http://www.verdadabierta.com/nunca-mas/38-desplazados/2676-icomo-se-fraguo-la-tragedia-de-losmontes-de-maria; and http://www.eltiempo.com/archivo/documento/MAM-444067

40. File No. 3239, ff. 65-66.

41. Supreme Court of Justice, Process 26918, February 21, 2007, f. 6.

42. Bogotá Chamber of Commerce, headquarters, April 26, 2007, Certification of existence and legal representation or registration of documents. 01FGRO042613007PPA0403, ff. 1-4. Ramírez had registered La Rubber with the Bogotá Chamber of Commerce in May 2005 and in August of the same year he changed, by notarial record, to a public limited company, by means of a fictitious sale of his shares to his bodyguards.

43. File No. 3239 , f.8.

44. Court Fourteen, cit., f. 3.

45. File No. 3239, ff. 1-6.

46. On the links of university directors with the framework of El Miki, see, for example, "The law of the jungle", Revista Cambio, March 9, 2007, retrieved April 3, 2011 from:

http://www.cambio.com.co/especialescambio/home/ARTICULO-PRINTER_FRIENDLY-

PRINTER_FRIENDLY_CAMBIO-3468900.html. On its trail in Monteviedo, see, "The Colombian gang operated from Montevideo; they exported to Europe forklift trucks with the fuel tank full of drugs", El Observador, Montevideo April 27, 2011, retrieved March 25, 2018 from https://www.elobservador.com.uy/el-pesado-historial-del-clan-ramirez-n200749

47. Radicado Sumario No. 3239, f. 51

48. Sentence No. 7, cit., ff. 5-9; 19-22.

49. Attorney General's Office, Filed 3239, cit. ff. 1-6.

50. Judgment No. 19 of the Fourth Criminal Court of the Specialized Circuit of Bogotá, 16 December 2009.

51. Concept favorable to Extradition to the United States, Supreme Court of Justice, Criminal Cassation Courtroom, 14 October 2009, Trial 31934. 
52. New York Southern District Attorney's Office Press Release, July 8, 2011:

http://www.justice.gov/usao/nys/pressreleases/July11/murciaguzmandavidsentencingpr.pdf retrieved August 12, 2012 and http://www.elespectador.com/noticias/judicial/david-murcia-guzman-condenadonueve-anos-de-prision-eeu-articulo-282937, retrieved August 14, 2012; but once his sentence is served, he will have to serve the remainder for 30 years: http://www.eltiempo.com/archivo/documento/CMS13008409 as ratified by the Bogotá Court in August 2013, recovered on 1 June 2014.

53. "Suspicious Business ", Cambio, January 5 to 11, 2007, No. 710, pp. 32-34; See also, http://m.semana.com/nacion/articulo/quien-quiere-millonario/90672-3

54. "Guillermo Rivera: the key witness for the victims of the pyramids and for the government", La Silla Vacía, March 10, 2011, retrieved March 29, 2018 from: http://lasillavacia.com/historia/guillermo-rivera-eltestigo-clave-para-los-damnificados-de-las-piramides-y-para-el-gobierno

55. Details of his visit to Pitalito were confirmed to me by Mr. Teódulo Guzmán, local coffee grower and leader of Dignidad Cafetera, in conversations held in Bogotá in June-July 2014.

56. Sentence No. 19 , op. cit. ff. 14-15, 87.

57. Sentence ibidem, f. 161

58. "Mancuso fought a fight that all of us from Cordoba should have fought", Semana, September 27, 2008 in, http://www.semana.com/nacion/articulo/mancuso-dio-lucha-hemos-debido-dar-todos-cordobeses/95594-3 retrieved April 12, 2012

59. Ibídem

60. Besides the fact that it was mere speculation that DMG was laundering money from Carlos Ramírez Abadía, alias Chupeta or Carlos Mario Jiménez, alias Macaco, it was not necessary for the Colombian Attorney General's Office to prove these specific connections. See, "David Murcia laundered dollars for Chupeta and Macaco", Semana.com September 20, 2012: http://www.semana.com/nacion/articulo/davidmurcia-lavaba-dolares-chupeta-macaco/246716-3; "Macaco and Chupeta would have laundered dollars with DMG", Semana Magazine, November 2008: http://www.semana.com/nacion/justicia/articulo/macaco-chupeta-habrian-lavado-dinero-dmg/97486-3

61. See recommendations on money laundering in http://www.fatfgafi.org/media/fatf/documents/recommendations/pdfs/FATF\%20Recommendations\%202012.pdf retrieved April, 2013.

62. Judgment No. 19 of the Fourth Criminal Court of the Specialized Circuit of Bogotá, 2009, f. 8.

63. Sentence No 19, cit., ff. 7160-161

64. See, "Capturing votes: the new DMG policy", Semana.com:

http://www.semana.com/politica/articulo/captar-votos-nueva-politica-dmg/104591-3 retrieved June 9, 2012; "DMG Party", Revista Semana, September 12, 2009:

http://www.semana.com/confidenciales/articulo/partido-dmg/107382-3 retrieved June 9, 2012; "DMG for president”, Semana.com: http://www.semana.com/elecciones-2010/en-campana/articulo/dmgpresidencia/113750-3 retrieved June 9, 2012.

65. From the fall of DMG to the blackmail of the Nule", in La Silla Vacia, April 16, 2014, retrieved March 22, 2018 from: http://lasillavacia.com/elblogueo/jcflorez/19560/de-la-caida-de-dmg-al-chantaje-de-los-nule. About two years after these episodes, it was made public that Luis C. Sarmiento Angulo bought the newspaper El Tiempo. See, "Sarmiento buys El Tiempo", Semana.com:

http://www.semana.com/nacion/articulo/sarmiento-compra-el-tiempo/255040-3 retrieved August 14, 2012.

66. Sentence No. 19 , cit., f. 154

67. "Government decides to step in DRFE operations", El Espectador, 12 noviembre 2008, retrieved June 16, 2012 from: http://www.elespectador.com/articulo90050-gobierno-decide-intervenir-operaciones-depiramide-drfe

68. "They fell down", Semana.com: http://www.semana.com/nacion/articulo/se-vinieron-piso/97339-3, retrieved June 10, 2012

69. Ibidem

70. "Uribe's son admits commercial relationship with DMG owner" in Telemetro.com, December 5, 2008, in http://www.telemetro.com/internacionales/Hijo-Uribe-relacion-comercial-DMG_0_101689832.html retrieved June 10, 2012. "The DMG Relationship Manager" in El Espectador, November 19, 2008: https://www.elespectador.com/impreso/tema-del-dia/articuloimpreso91837-el-relacionista-de-dmg retrieved July 13, 2012; "DMG owner affirms that Uribe's sons are doing business with him", en Vanguardia. com: http://www.vanguardia.com/historico/12956-dueno-de-dmg-asegura-que-hijos-de-uribe- 
hacen-negocios-con-el retrieved July 13, 2012; "Uribe's sons admits link to DMG”, May 12, 2008, in contrabalboa: https://contrabalboa.wordpress.com/2008/12/05/hijo-de-uribe-reconoce-relacion-con-dmg/ retrieved April 11, 2012; "Son of president Uribe admits ties with fraudster company", in La Jornada (Mexico) December 6, 2008, retrieved May 15, 2014 in:

http://www.jornada.unam.mx/2008/12/06/index.php?section=mundo\&article=030n1mun

71. See, http://m.semana.com/nacion/articulo/escandalo-venganza/101762-3

72. For example, see the narration of the confrontation that DMG provided to Claudia Gurisatti, in the show "La Noche de RCN", updated August 16, 2011: http://www.youtube.com/watch?v=Kmd6iyiGyKQ;On a billboard "Banks enslave us" El Espectador, January 25, 2010, retrieved June 14, 2012 from: http://www.elespectador.com/dmg/imagen-dmg-campana; on financing Uribe's reelection campaign in 2009, See, María Jimena Dusán, "The DMG Wild Card”, in, http://www.semana.com/opinion/articulo/elcomodin-dmg/101290-3; retrieved February 23, 2011.

73. "If the President is against DMG, customers will be against the government", in El Espectador, November 14, 2008, in https://www.elespectador.com/articulo90558-si-el-presidente-esta-contra-de-dmg-los-clientesestaran-contra-del-gobierno retrieved March 6, 2012. "DMG: the empire strikes back", Semana, November 14,2008 , in

http://www.semana.com/economia/articulo/dmg-imperio-contraataca/97316-3 retrieved February 11, 2011.

74. "Abelardo De la Espriella, one of DMG's lawyers", Semana Magazine, November 18, 2008: http://www.semana.com/nacion/multimedia/abelardo-espriella-abogados-firma-dmg/141690-3 retrived May 22, 2014; "De la Espriella quits from DMG's defense", Semana Magazine, November 20, 2008, retrieved May 22, 2014 from: http://www.semana.com/nacion/problemas-sociales/articulo/de-espriellarenuncio-defensa-dmg/97497-3

75. Sentence No 19, cit., f. 167.

76. Ibid., ff. 149-151. "DMG property at auction", La Estrella de Panamá, January 1, 2010 in http://laestrella.com.pa/panama/nacional/bienes-remate/23689969 retrieved February 16, 2011.

77. Ibidem, ff.151

\section{REFERENCES}

Abadinsky, H. (1990). Organised Crime. Chicago, Ill: Nelson Hall

Arocha, J. (1998). Los afrocolombianos. Bogotá: Instituto Colombiano de Cultura Hispánica

Ballvé, T. (2011). Territory by Dispossession: Decentralization, Statehood, and the Narco Land-Grab in Colombia. A Paper Prepared for the: "International Conference on Global Land-Grabbing", April 6-8, 2011. Organized by the Land Deals Politics Initiative (LDPI) in collaboration with the Journal of Peasant Studies.

Barth F. F. (ed.) (1963). The Role of the Entrepreneur in Social Change in Northern Norway. Bergen: Arok for Universitect I Bergen.

Belshaw, C.S. (1955). The Cultural Milieu of the Entrepreneur: A Critical Essay. Explorations in Entrepreneurial History, 7(3), 146-163.

Bourdieu, P. (1987). Choses dites. Paris: Minuit.

Braudel, F. (1968). La historia y las ciencias sociales. Madrid: Alianza Editorial.

Departamento Nacional de Planeación. (2007). Plan Nacional de Desarrollo 2006-2010. Estado Comunitario: Desarrollo para todos. Bogotá: Departamento Nacional de Planeación.

Domínguez, C. (1986). Prólogo, en J. E. Jaramillo, L. Mora y F. Cubides, Colonización, coca y guerrilla. Bogotá: Universidad Nacional.

Escobar, A. (2003). Displacement, Development, and Modernity in the Colombian Pacific. International Social Science Journal, 55, 157-167.

Franco R. V. L., y Restrepo E. J. D., (2011). Empresarios Palmeros, poderes de facto y despojo de tierras en el Bajo Atrato. en La economía de los paramilitares. Redes de corrupción, negocios y política (Romero Vidal, M. (ed.), Bogotá: Debate/Corporación Nuevo Arco Iris, 269-410.

Gouëset, V. (1999). El territorio colombiano y sus márgenes. La difícil tarea de la construcción territorial, en Bogotá. Territorios, 1, 77-94. 
Grajales, J. (2011). The Rifle and the Title: Paramilitary Violence, Land Grab and Land Control in Colombia. The Journal of Peasant Studies, 38(4), October, 771-792.

IGAC/CEDE, Universidad de los Andes. (2012). Atlas de la distribución de la propiedad rural en Colombia, Bogotá: Imprenta Nacional de Colombia.

Krauthausen, C. (1998). Padrinos y mercaderes. Crimen organizado en Italia y Colombia. Bogotá: Planeta Colombiana Editorial

Moore, J. W. (2000). Sugar and the Expansion of the Early Modern World-Economy: Commodity Frontiers, Ecological Transformation, and Industrialization. En, Review (Fernand Braudel Center), 23(3), 409-433.

Ocampo, G. I. (2007). La instauración de la ganadería en el valle del Sinú. La hacienda Marta Magdalena, 1881-1956. Medellín: Universidad de Antioquia.

Ortiz, C.M. (1998). Urabá: tras las huellas de los inmigrantes 1955 a 1990. Bogotá: Icfes.

Palacios, M. (1980). Coffee in Colombia, 1850-1970. An economic, social and political history. Cambridge, UK., Cambridge University Press.

Palacios, M. (2002). .Un presidente de a caballo. El País, Madrid, 7 de agosto de 2002, p. 16 recuperado el 3 mayo 2012 en http://elpais.com/diario/2002/08/07/internacional/1028671207_850215.html

Palacios, M. (2011). ¿De quién es la tierra? Propiedad, politización y protesta campesina en la década de 1930. Bogotá: Fondo de Cultura Económica/Universidad de los Andes.

Palacios, M. (2012). Violencia Pública en Colombia, 1958-2010. Bogotá: Fondo de Cultura Económica.

Palacios, M. (2012 A). A Historical Perspective on Counterinsurgency and the "War on Drugs in Colombia", in Cynthia J. Arnson (Ed.), In the Wake of War: Democratization and Internal Armed Conflict in Latin America. Stanford University Press, 175-206

Pineda Camacho, R. (2001). Sociedades heridas, el desafio de una nación multicultural en un escenario de conflicto. Bogotá: Universidad de los Andes.

Ramírez, M. C. (2014). Legitimidad, complicidad y conspiración: la emergencia de una nueva forma económica en los márgenes del Estado en Colombia, en Antípoda. Revista de Antropología y Arqueología. Bogotá, 8, 29-59.

Reales, L. (2011). Ethnic Minorities and Human Rights. The Afro-Colombian Case, en Revista Latinoamericana de Derechos Humanos, 22(1), 153-175.

Roldán, M. (2003). A sangre y fuego. La Violencia en Antioquia, Colombia, 1946-1953. Bogotá: Instituto Colombiano de Antropología .

Rosental, P. A. (1996). Construire le macro par le micro, F. Barth et la microstoria, en J. Revel (Comp.) Jeux d'echelles, la micro-analyse à la expérience. Paris: Gallimard-Le Seuil

Steiner, C. (2000). Imaginación y poder. El encuentro del interior con la Costa en Urabá, 1900-1960. Medellín: Universidad de Antioquia.

Taussig, M. (2012) Chamanismo, colonialismo y el hombre salvaje: un estudio sobre el terror y la curación. Popayán: Universidad del Cauca.

Taylor, I. (1997). The Political Economy of Crime, en The Oxford Handbook of Criminology, Oxford: Clarendon Press, 265-303.

Vargas Silva, L.E. (2011). Temas selectos de Derecho Constitucional. Interpretación Jurisprudencial. Bogotá: Universidad Libre, 49-96

Vélez, M.A. (2009). Sistemas complejos de gobierno local: Reflexiones sobre la titulación colectiva en el Pacífico vallecaucano. Revista de Estudios Sociales, 32, 74-85.

Vélez, M.A. (2011). Collective Titling and the Process of Institution Building: The New Common Property Regime in the Colombian Pacific. Human Ecology, 39, 117-129.

Wade, P. (1993). Blackness and Race Mixture: The Dynamics of Racial Identity in Colombia. Baltimore: The Johns Hopkins University.

World Bank. (2004). Colombia, Land Policy in Transition. Washington, D.C., World Bank Publications.

Wouters, M. (2001). Ethnic Rights under Threat: The Black Peasant Movement against Armed Groups' Pressure in the Chocó, en, Bulletin of Latin American Research, 20(4), Special Issue: Armed Actors in Latin America in the 1990s, 498-519. 